\title{
Existential Angst in Kate Chopin's The Story of an Hour
}

\author{
Kishor Paudel \\ Nepal Commerce Campus, T.U.
}

\begin{abstract}
The present article on Kate Chopin's The Story of an Hour (1894) explores women's anxieties and struggles for self identity within the arena of strict social and traditional structures deeply rooted in the then American society in the late nineteenth century. Through this short story, Chopin portraits her feminist view and uses her own inspiration for surviving normal life in the mind of the American women for whom existing freely realizing their identity and potentiality had been a far cry. Thus, drawing upon the idea of Simone de Beauvoir and other writers, this paper examines the desire and struggle of the female protagonist, Mrs Mallard for her meaningful existence in the male-dominated society in America. Key Words Feminism, existential angst, suppression, freedom, patriarchy
\end{abstract}

\section{Introduction}

Set in the late $19^{\text {th }}$ century America, Kate Chopin's The Story of an Hour craftily dramatizes the anxieties and sufferings of a woman at the domain of patriarchal norms and values. Mrs. Mallard, the protagonist of the story, confronts with the contemporary society for the sake of her freedom and identity in order to exist on her own enjoying the self-defining choices. The projection of powerful female who needs to struggle to achieve liberation from the shackles of her husband gives the story an essence. The assumption is that Mrs. Mallard needs to free herself from the patriarchal suppression in order to enjoy her personal life. However, the existing social values and domination from her own husband shatter her aspiration of living and enjoying in her personal world. The purpose of this paper is to explore the existential angst of the protagonist, Mrs. Mallard which she experiences being trapped in a loveless marriage within a constrictive house.

The intended term-angst refers to a strong feeling of being worried or nervous: a feeling of anxiety about life or situation. In this sense, existential angst refers to the state of having anxiety while finding self and the meaning of life through free will, choice and personal responsibility. Humans want to make choice based on their beliefs, views and personal experiences after perceiving the world. Since the nature of an individual is different, so are his/her life choices. But in the patriarchal society, making choices on part of women has always been a difficult decision. The women are considered to possess limited knowledge regarding philosophical, religious, and political ideologies even if the reality is different. Simone de Beauvoir in her book 'The Second Sex' argues that "The curse upon woman as vassal consists... in the fact that she is not permitted to do anything: so she persists in the vain pursuit of her true being through narcissism, love or religion" (641). Women are often treated as weak, passive, emotional, dependent, submissive, illogical and innocent beings. Even though they try to fulfil their duties honestly and responsibly, the patriarchal society does not view them equal to men. They are compelled to hide their feelings and emotions for the sake of male members of the family and society. They get tired looking at exploitation and suppression that has been done to them. They suffer from anxiety, depression and psychological turmoil. The condition 
becomes so horrible that they are likely to imagine pleasure at death only. So observing the physical and psychological domain which the women undergo, Beauvoir argues, "All the problems of life find a silent solution in death; a woman who is busy with living is therefore more variance with herself than is she who buries her will and her desires" (647).

Kate Chopin's thousand-word short story The Story of an Hour deals with the themes of confinement and restriction, physically and emotionally. The setting of the story is of the house with personal room, and upon reading the story the readers begin showing their sympathy towards the protagonist's deteriorating health problem. She is the one as Chopin writes, "who was afflicted with heart trouble" (Bullock, 280) and precautions needed to be taken to announce her "husband's death" by her sister and her husband's friend. This makes the readers wonder that Mrs. Mallard's heart ailment may have resulted from the stress caused by her reaction to her inferior status in a male-dominated culture where the marriage is not an ideal one. After she hears that he has died in the so-called train accident, she starts weeping at once. However, she does not take this issue as seriously as "many women have heard the same, with a paralyzed inability to accept its significance" (280). A strong desire for bringing about change leads her to create a new life because she has been victimised for the sense of freedom and joy. Since she does not want to reveal the truth about what is going on inside her mind, she slowly goes inside her room and confines herself in order to achieve the physical and mental state she desires. She wants to be by herself, so instead of going out into the world and losing herself in a crowd, she tries to hold her body and mind within just one room. She thinks the room is the only private place where she can free herself from the burdens of domestic life.

The story further reveals that the open window and the comfortable, roomy armchair do not give her a sense of eternal happiness. Even in her private room, she suffers being "pressed down by a physical exhaustion that haunted her body and seemed to reach into her soul" (280). In the same manner, the role of imagery seems to be effective while relieving herself from the uncertainty of life. It is the spring season and the birds are singing. The trees burst with new life. Though it has been raining, patches of sky blue sky appear. By observing the outside world, she wants to reduce her anguish in life. And it is for this reason that she imagines the world to suit her expectation to a large extent. All of sudden she begins to realize as an independent woman and whispers, "Free, free, free!" (281). This state of mind of the protagonist proves that longing to be a free woman is in her unconscious level. Now she finds the world ahead of her belonging to herself. She intends to remain happy and begins to realize a "monstrous joy". She apprehends that her existence is about to be meaningful but in vain. In spite of her life of disillusionment, she wishes to enjoy a "long procession of years to come that would belong to her absolutely" (281). This self-assertion brings a strong impulse of her being, though momentarily. Her struggle is certainly against the values of patriarchal domination, not like what Lawrence I. Berkove in his article views: "there is no hard evidence whatsoever of patriarchal blindness or suppression, constant or selfless sacrifice by Louise, or an ongoing struggle for selfhood" (153). There are many instances to indicate how Mrs. Mallard has been victimized in terms of love, marriage and sex, otherwise she would not perceive the upcoming years of her life with monstrous joy. The concern presented in this story by Chopin perceptibly shows the matter of marriage and family constriction in which Mrs. Mallard suffers through painful experience. Again in Berkove's words, "Chopin did not regard marriage as a state of pure and unbroken bliss" (157). This makes the sense that Mrs. Mallard's life has got noxious traces of marriage and love.

Everyone basically agrees that human life is in no way complete and fully satisfying because of suffering and losses that occur when considering the lack of perfection, power, and control one has over their life. Even though they do agree that life is not optimally satisfying, it nonetheless has meaning. Existentialism is the search and journey for true self and true personal meaning in life. This can be further made clearer through the name that the protagonist possesses in the story. Unnoticed and uninformed to the readers, Mrs. Mallard is called by her first name by her sister Josephine for the first time. In fact, her name, Louise is associated with the masculine name Louis and she receives this name only when she starts regaining her own identity. Her sister is worried because she thinks that her confinement within the room 
Vol. 4, No. 1

might prove to be regretful. Hence, she pleads Mrs. Mallard honestly, "Louise, open the door! I beg; open the door -you will make yourself ill" (Bullock, 281). Here, the reader notices that Mrs. Mallard is compelled to limit her sense of being when she traps herself alone in the room.

Marriage of course restricts freedom. Mrs. Mallard does not seem to be happy in her married life. Her expression regarding the frustration of marriage is clearly stated in the story as: "It was only yesterday she had thought with a shudder that life might be long" (281) without her husband's suppression. This is why she cannot think of coming back to her as usual life and get the complete satisfaction. At last she dies due to the shock she gets after noticing her husband alive. Though the doctors conclude that "she had died of heart disease-of joy that kills" (282), it is not the bliss that kills her. The reason behind it is the loss of freedom that completely shatters her sense of being. If it was not the matter of existential predicament, she would not have this shock any more at the arrival of her husband. So Chopin's The Story of an Hour according to Mary E. Papke clearly "details a very ordinary reality and conscientiously analyzes that moment in a woman's life when the boundaries of the accepted everyday world are suddenly shattered and the process of self-consciousness begins" (52). What is important in the story is the conflict between liberation and social conformity that is fundamental in establishing a woman's identity in search of her self-defining choices. According to Negin Karami and Esmaeil Zohdi, "Louise insists to rebel with the strongest role to seek a clear sense of self and enables herself to deal with outer space not by adapting to male roles, but with her freedom, and with her idea and new free life" ( 433). This indicates how Chopin through the portrayal of female protagonist, Mrs. Mallard portrays the significant role of women in defying their destiny to fulfil their desires and choices. As an exemplary writer, she shows increasing concern for women in Victorian age America and responds with appalling writings dealing explicitly with love, sex and marriage.

In conclusion, through The Story of an Hour Kate Chopin believes that women cannot easily realize their freedom and selfhood without any resistance in the patriarchal society. The treatment of the woman character is against notions of femininity and domesticity of the century. And the protagonist seems to rebel such manacles by making her choices of personal freedom even in such critical time of powerful maledomination.

\section{Works Cited}

Beauvoir, Simone de (1953). The Second Sex. Ed. H. M. Parshley. Lowe and Brydone (Printers) Ltd.

Berkove, Lawrence I. (winter, 2000). "Fatal Self-Assertion in Kate Chopin's 'The Story of an Hour '”. American Literary Realism, vol. 32, no. 2. pp. 152-158.

Bloom, Harold (2007). “Bloom's Modern Critical Views: Kate Chopin - Updated Edition”. Bloom's Literary Criticism. PP 52-54.

Bullock, Richard, and Francine Weinberg (2009). The Norton Field Guide to Writing with Handbook. $2^{\text {nd }}$ ed. W. W. Norton \& Company.

Karami, Negin, and Esmaeil Zohdi (July-Sep. 2015). "Kate Chopin's The Story of an Hour”: A Feminist Interpretation". Research Journal of English Language and Literature (RJELAL). KY Publications, vol 3.3. pp. 430-435. 